ISSN 0258-7122

Bangladesh J. Agril. Res. 40(2): 189-204, June 2015

\title{
DETERMINATION OF OPTIMUM MATURITY STAGE OF BANANA
}

\author{
M. N. AMIN ${ }^{1}$, M. M. HOSSAIN ${ }^{2}$, M. A. RAHIM ${ }^{3}$ AND M. B. UDDIN ${ }^{4}$
}

\begin{abstract}
Time of harvest based on maturity indices is very important for fruit quality. Fruits harvested before optimum maturity may not ripe adequately and may not develop adequate flavor, while fruits harvested late (over-matured) have a shorter postharvest life and deteriorate rapidly. Climacteric fruits can be harvested after reaching full maturation, and before reaching the ripening stage. The tissue culture suckers of BARI Kola1 and Sabri Kola varieties were used for the study. The experiment was conducted at the Farm Machinery and Postharvest Process Engineering Division, Bangladesh Agricultural Research Institute, Gazipur in 2009-10. Optimum maturity stage of banana fruits reduced the postharvest losses and extended the storage life of fruits. BARI Kola 1 and Sabri Kola reached to flowering stages 10 and 15 months after planting, respectively. The optimum maturity stages of BARI Kola 1 and Sabri Kola were found to 120 and 100 days after emergence of flowering (DAEF) in summer and 130 and 110 DAEF in winter seasons, respectively. Higher pulp to peel ratio and yield of both the varieties was found in summer than those of winter season. The pre-harvest loss of banana fruits started at the point when it just exceeded the optimum maturity stage. Decreasing trend of shelf-life and firmness of fruits for both the varieties were observed with the advancement of maturity. On the other hand, dry matter content, angularity, pulp to peel ratio, and yield of banana fruits increased with the advancement of harvesting days. Degree days of these varieties were found to be 1750 and 1620 , respectively.
\end{abstract}

Keywords: BARI Kola 1, Sabri Kola, optimum maturity stage, shelf-life, degree days and physico-chemical properties.

\section{Introduction}

Fruit maturation is an important postharvest criterion for banana. The stage of maturation at which the fruit is harvested greatly influences the green-life or storage lo5ngevity and eating quality. Every fruit attains its full characteristics e.g. flavour, taste and colour during storage if it is picked at optimum time. Fruits, harvested at an advanced stage of maturity, is not suitable for fruits intended for long distance transportation due to their shorter storage life (Harman, 1981; Kader, 1994).

\footnotetext{
${ }^{1}$ Senior Scientific Officer, Farm Machinery and Postharvest Process Engineering Division, Bangladesh Agricultural Research Institute (BARI), Gazipur, ${ }^{2}$ Professor, Farm Power and Machinery, Bangladesh Agricultural University (BAU), Mymensingh, ${ }^{3}$ Professor, Horticulture, BAU, ${ }^{4}$ Professor, Food Technology and Rural Industries, BAU, Mymensingh. Bangladesh.
} 
Most of the banana plants produce the flower buds within 10 to 15 months of emergence as a new sucker, depending mostly on variety and extent of cool weather. Banana production systems are perennial. Flower development is initiated from the true stem portion of the plant 9-12 months after planting. The inflorescence grows up through the center of the pseudostem. Depending on season and cultivar, bananas become matured at 90-120 days after appearing of first flower (Knowledge Master, 2003).

According to Morton (1987), banana bunches are harvested when the fruits are fully developed, that is, $75 \%$ matured, the angles are becoming less prominent and the fruits on the upper hands are changing to light green; and the flower remnants (styles) are easily rubbed off the tips. Generally, this stage reached 75 to 80 days after the opening of the first hand.

Harvesting of banana is done 12 to 15 months after planting in dwarf and 15 to 18 months after planting in tall varieties. Signs of maturity of banana fruits are: fruit becomes plumpy and angles are filled in completely; gives metallic sound when tapped, drying up of top leaves and change in colour of fruits from deep green to light green (Mpyshameem, 2010). Ara et al. (2009) reported that crop durations of Sabri and BARI Kola 1 was 412 days and 435 days, respectively.

Fruit characteristics at harvest may be important in the design of packaging for the fruit which would enhance efficient handling and transportation. Postharvest quality attributes (such as peel and pulp colour, pulp firmness, total soluble solids, moisture and dry matter content) are important to assess the maturity indices (Dadzie and Orchard, 1997). Optimum maturity stage of banana is important for attaining good quality fruits and optimum storage life of fruits. No information on maturity stages of varieties of BARI Kola 1 and Sabri Kola is available in the country. Therefore, this study was undertaken to determine the optimum maturity stages of BARI Kola 1 and Sabri Kola on the basis of different physico-chemical properties.

\section{Materials and Method}

\section{Variety Selection}

Two varieties of BARI Kola 1 and Sabri Kola were selected which were available in the local market in Bangladesh. One hundred fifty tissue culture suckers of BARI Kola 1 and same numbers of Sabri Kola were collected from Proshika, Manikgonj.

\section{Cultivation of Selected Variety}

Land preparation was done by disc ploughing and harrowing, the pits were dug for planting. Each pit size was $60 \times 60 \times 60 \mathrm{~cm}$. Organic manures and fertilizers were applied in pit as well as top-dressing as per recommendation of Haque 
(1988). Entire quantity of cow dung, TSP, gypsum, zinc oxide, boric acid and half of muriate of potash were applied in each pit one week after digging. Cowdung was mixed well with the pit soil while fertilizers were incorporated into top $10 \mathrm{~cm}$ soil by light spading.

\section{Planting}

The pits were filled with manures and fertilizers after one week. Selected sucker of uniform size of BARI Kola 1 and Sabri Kola were planted in the pits on 9 March 2008. The plot size was $3 \times 3 \mathrm{~m}$ and 4 suckers were planted per plot maintaining a distance $2 \times 2 \mathrm{~m}$ in the field.

Matured bunches of BARI Kola 1 and Sabri Kola were harvested in summer in 2009-10 at six maturity stages at 10 days interval such as 100,110,120,130,140, and 150 and 80,90,100,110,120, and 130 days after emergence of shooting, respectively. They were also harvested in winter 2009-10 at same maturity stages. To reduce variation and to obtain consistent data, all measurements were limited to (or taken on) the fingers of the second hand of freshly harvested physiologically matured bunches (with green fruit). However, if there were not enough samples, fruits from the third and fourth hand were included. Matured and uniform fingers of these selected hands were taken and washed them in fresh water. Fifteen fingers of banana were randomly separated for each treatment and taken five fingers for each replication. Three replications were used to carry out the each treatment.

\section{Shelf-life}

Shelf life (days) of banana fruit of each treatment was recorded during the period of storage. It was calculated from the date of harvesting to last edible stage.

\section{Determination of angularity or degree of roundness}

Fruit angles were determined at 3 points on the outer surface by measuring individual fruit with a stainless steel protractor. Angularity of fruit was expressed as degree.

\section{Measurement of moisture and dry matter content}

Empty container (aluminum dish) was weighed on electronic micro balance and recorded it (A). Chopped fresh pulp samples were put into the container and weighed it (B). The samples were placed in an air ventilated electric oven at 100 ${ }^{\circ} \mathrm{C}$ for 24 hours (Kushman et al., 1966). The samples were transferred with the container from oven into desiccators and cooled at room temperature and weighed to obtain the dry samples (C). 
Percentage moisture and dry matter content of the samples were calculated by using the following formula.

$$
\begin{array}{ll}
\text { Wet weight of sample } & (\mathrm{D})=\mathrm{B}-\mathrm{A} \\
\text { Dry weight sample } & (\mathrm{E})=\mathrm{C}-\mathrm{A} \\
\text { Moisture content, }(\%)(\mathrm{db}) & =\frac{D-E}{E} \times 100
\end{array}
$$

\section{Pulp to peel ratio}

Pulp and peel were separated, weighed individually and expressed as pulp to peel ratio (i.e. pulp weight divided by the peel weight).

\section{Determination of total soluble solids (TSS)}

The total soluble solids of banana pulp were determined by using a refractometer. Thirty g of pulp tissue was homogenized with $90 \mathrm{ml}$ of distilled water using a kitchen blender for two minutes and filtered through a filter paper $12.5 \mathrm{~cm}$ qualitative. Before measurement, the refractometer was calibrated with distilled water to give a 0 (zero) reading. A single drop of the filtrate was placed on the prism to obtain the TSS reading. The recorded value was multiplied by three (because the initial pulp sample was diluted three times with distilled water).Temperature corrections were made by using the methods described by manufacturer manual.

\section{Determination of firmness}

Fruit firmness was measured using digital firmness tester equipped with a $8 \mathrm{~mm}$ and $5 \mathrm{~mm}$ diameter cylindrical stainless probes. Tester was checked each day before use. The plunger was made to work in and out (about ten times) to ensure that it was running smoothly. Fruit firmness was expressed in kilogram force $\left(\mathrm{kg}_{\mathrm{f}}\right.$ $\mathrm{cm}^{-2}$ ). Three readings were taken at three places on the surface of each banana and the mean value was calculated.

\section{Degree days}

The degree days were obtained by multiplying the daily mean temperature above $10{ }^{\circ} \mathrm{C}$ by number of days starting from full bloom to harvest (Jindal, 1985).

\section{Statistical analysis}

Data were statistically analyzed using MSTATEC software by analysis of variance and significant differences among the treatments were determined using Duncan's Multiple Range Test at $\mathrm{P} \leq 0.05$. 


\section{Results and Discussion}

\section{Degree of roundness/angularity of banana fruit}

The effect of harvesting days on degree of roundness and firmness of BARI Kola1 during summer and winter seasons is shown in Figure 1. Angularity of fruit surface sharply increased up to 120 and 130 days of harvesting for summer and winter, respectively. Later they increased slowly and towards steady state with the increase of harvesting days. The highest and the lowest degree of roundness of BARI Kola 1 in summer and winter were 147.94, 146.66 and $134.06,132.13^{\circ}$ for 100 and $150 \mathrm{DAEF}$, respectively.

Effect of harvesting days on degree of roundness and firmness of fruit of Sabri Kola in summer and winter seasons is shown in Figure 2. The degree of roundness of fruits of Sabri Kola increased sharply with the advancement of days of harvesting in both the seasons. The maximum and minimum values were found to be 150.48 and 144.24 degree for summer and 146.78 and 138.11 degree for winter, respectively. The differences in values of degree of roundness in two seasons were from climatic effects. The stages of harvesting showed significant variation in respect of angularity.

In respect of seasons, angularity of BARI Kola 1 and Sabri Kola was significant (Table 1). Result indicated that summer was superior to winter in respect of angularity. Irrespective of seasons, harvesting stages of both the varieties exhibited significant effect on angularity (Table 2). Treatment combinations also did not have any significant effect in respect of angularity for both the varieties.

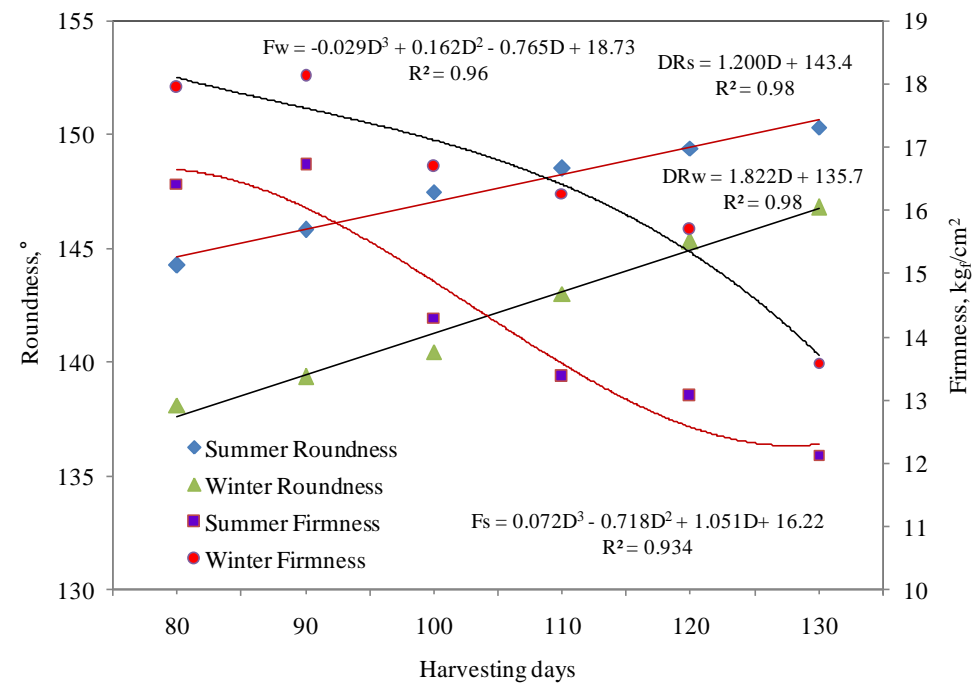

Fig.1. Effect of harvesting days on roundness and firmness of BARI Kola1. 


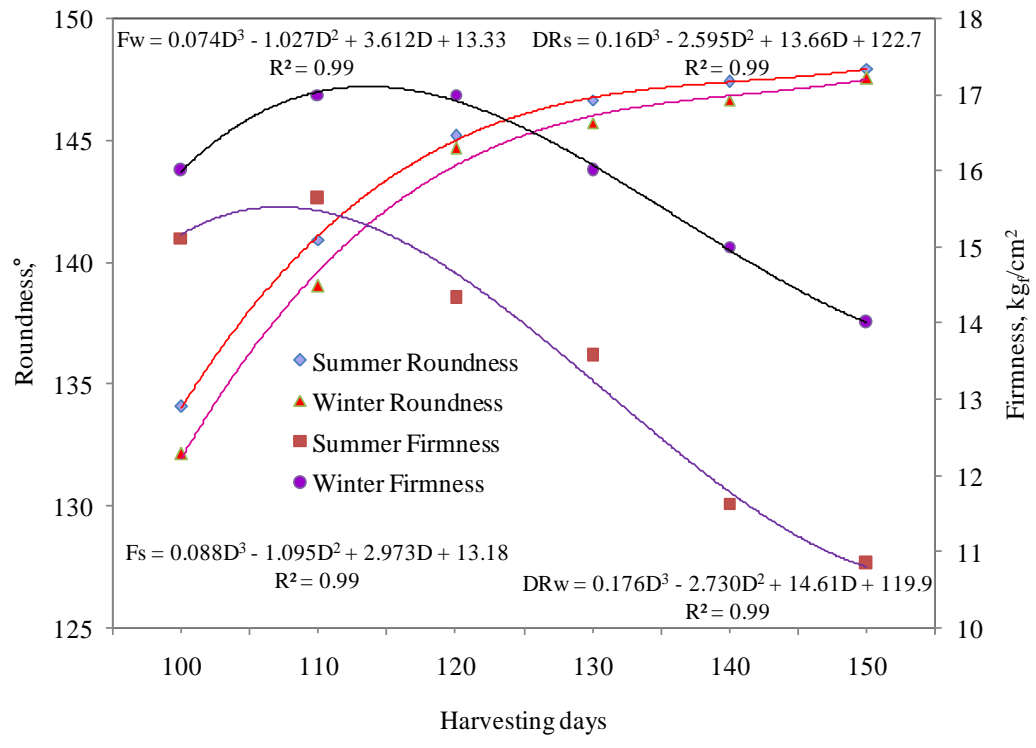

Fig. 2. Effect of harvesting days on roundness and firmness of Sabri Kola.

\section{Firmness}

Firmness of fruit of BARI Kola 1 and Sabri Kola gradually increased and then decreased with the advancement of harvesting days (Figure 1 and 2). It was also observed that firmness of BARI Kola 1 in summer and winter seasons increased towards maturity from 100 to 110 and 100 to 120 days after emergence of flowering (DAEF), respectively, and thereafter gradually declined up to 150 DAEF. It means fruits were tender initially and progressed towards the hardness with morphological advancement. It became soft at maturity stages. Optimum maturity stages of BARI Kola 1 might be laid between 110 to 130 DAEF for summer and 120 to 140 DAEF for winter. In summer, firmness under harvesting stages of 100,110, 120 and 130 were statistically identical, but harvesting stages of 140 and 150 showed significant decrease in firmness.

In winter, significant variation was observed among the harvesting stages in respect of firmness. In respect of seasons, firmness of BARI Kola 1 varied significantly (Table 1). The finding indicated that firmness of BARI Kola 1 in winter was higher than that in summer. It might be due to the reason that fruit peel tissue got harder due to cold weather. At the stage of harvesting significant variations in firmness of fruits were found for both the seasons (Table 2). 
Table 1. Effect of season on angularity and firmness of BARI Kola 1 and Sabri Kola.

\begin{tabular}{c|c|c|c|c}
\hline \multirow{2}{*}{ Season } & \multicolumn{2}{|c|}{ BARI Kola 1 } & \multicolumn{2}{c}{ Sabri Kola } \\
\cline { 2 - 5 } & $\begin{array}{c}\text { Angularity } \\
\text { (degree) }\end{array}$ & Firmness $\left(\mathrm{kg}_{\mathrm{f}} \mathrm{cm}^{-2}\right)$ & $\begin{array}{c}\text { Angularity } \\
(\text { degree })\end{array}$ & Firmness $\left(\mathrm{kg}_{\mathrm{f}} \mathrm{cm}^{-2}\right)$ \\
\hline Summer & $143.70 \mathrm{a}$ & $13.52 \mathrm{~b}$ & $147.70 \mathrm{a}$ & $14.33 \mathrm{~b}$ \\
Winter & $142.67 \mathrm{~b}$ & $15.93 \mathrm{a}$ & $142.16 \mathrm{~b}$ & $16.49 \mathrm{a}$ \\
\hline
\end{tabular}

Table 2. Effect of harvesting days on angularity and firmness of BARI Kola 1 and Sabri Kola.

\begin{tabular}{|c|c|c|c|c|c|}
\hline \multirow{2}{*}{$\begin{array}{l}\text { Harvesting } \\
\text { days }\end{array}$} & \multicolumn{2}{|c|}{ BARI Kola 1} & \multirow{2}{*}{$\begin{array}{c}\text { Harvesting } \\
\text { days }\end{array}$} & \multicolumn{2}{|c|}{ Sabri Kola } \\
\hline & $\begin{array}{c}\text { Angularity } \\
\text { (degree) }\end{array}$ & $\begin{array}{l}\text { Firmness } \\
\left(\mathrm{kg}_{\mathrm{f}} \mathrm{cm}^{-2}\right)\end{array}$ & & $\begin{array}{l}\text { Angularity } \\
\text { (degree) }\end{array}$ & $\begin{array}{l}\text { Firmness } \\
\left(\mathrm{kg}_{\mathrm{f}} \mathrm{cm}^{-2}\right)\end{array}$ \\
\hline 100 & $133.10 \mathrm{c}$ & $15.76 \mathrm{ab}$ & 80 & $141.20 \mathrm{~d}$ & $17.30 \mathrm{a}$ \\
\hline 110 & $140.00 \mathrm{~b}$ & $16.52 \mathrm{a}$ & 90 & $142.60 \mathrm{~cd}$ & $17.47 \mathrm{a}$ \\
\hline 120 & $145.10 \mathrm{a}$ & $15.46 \mathrm{ab}$ & 100 & $144.00 \mathrm{c}$ & $15.56 \mathrm{~b}$ \\
\hline 130 & $146.20 \mathrm{a}$ & $14.68 \mathrm{bc}$ & 110 & $146.00 \mathrm{~b}$ & $14.66 \mathrm{~b}$ \\
\hline 140 & $147.00 \mathrm{a}$ & $13.42 \mathrm{~cd}$ & 120 & $147.20 \mathrm{ab}$ & $14.54 \mathrm{~b}$ \\
\hline 150 & $147.70 \mathrm{a}$ & $12.52 \mathrm{~d}$ & 130 & $148.60 \mathrm{a}$ & $12.93 \mathrm{c}$ \\
\hline $\mathrm{CV}(\%)$ & 1.18 & 7.47 & $\mathrm{CV}(\%)$ & 1.18 & 7.47 \\
\hline
\end{tabular}

* Similar letter(s) in a column do not differ significantly by at $5 \%$ lebel of probability DMRT

\section{Total soluble solids}

Pulp to peel ratio (Pp) and total soluble solids (TSS) of BARI Kola 1 in summer and winter seasons were changed with the harvesting stage (Figure 3). It was observed that TSS increased initially but became almost constant in advanced stages of maturity. At immature stage, TSS value was lower than that of maturity stage while it was in similar state from maturity stage of 120 DAEF in both seasons. It was found that the fruits attained maturity condition from 120 to 130 DAEF. Optimum maturity stage ranged between 120 and 130 DAEF in summer and 130 and 140 DAEF in winter season. In summer, TSS was similar at 120, 130,140 and 150 days of the harvesting but they significantly differed at 100 and 110 days of harvesting. In winter, TSS at 110, 120, 130, 140 and 150 days of harvesting was observed similar but they differed significantly at 100 days of harvesting (Table 3). 
TSS content of Sabri Kola increased gradually as the harvesting days advanced towards optimum maturity (Figure 4). Harvesting days had no significant effect on TSS content in summer but had significant effect on the TSS content in winter (Table 3). In winter, harvesting days of 100, 110, 120 and 130 were similar but differed in harvesting days of 80 and 90. Significant difference was observed between the seasons in respect of TSS (Table 3). TSS was higher in winter than that of summer. For both seasons, significant variation among the harvesting days was found in respect of TSS (Table 4).

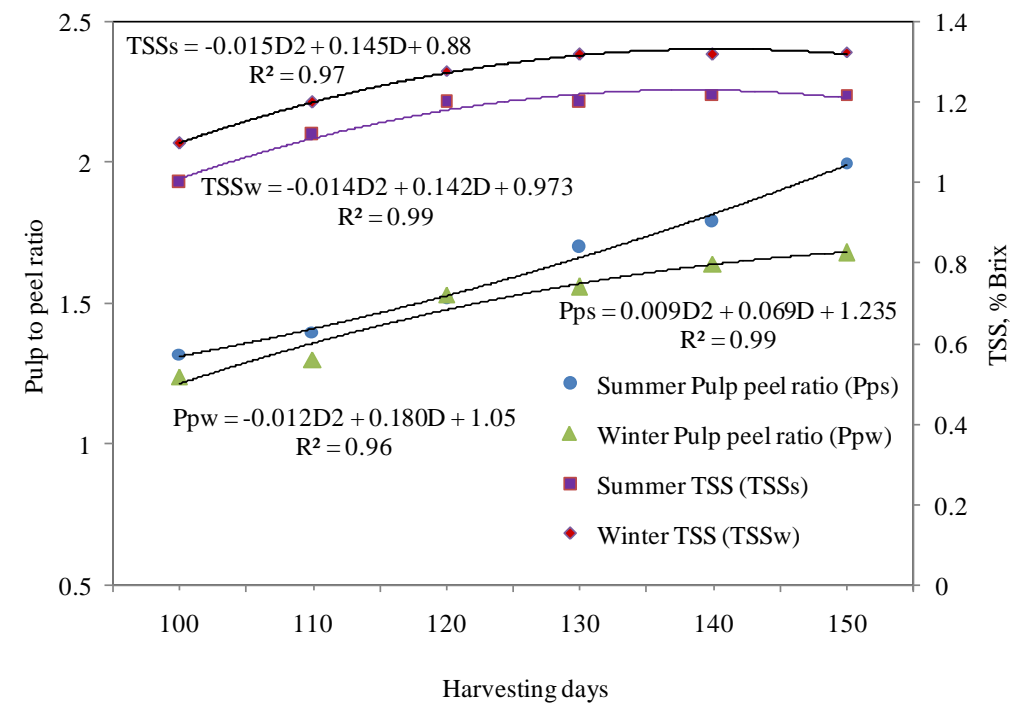

Fig.3. Effect of harvesting days on pulp to peel ratio and TSS of BARI Kola 1.

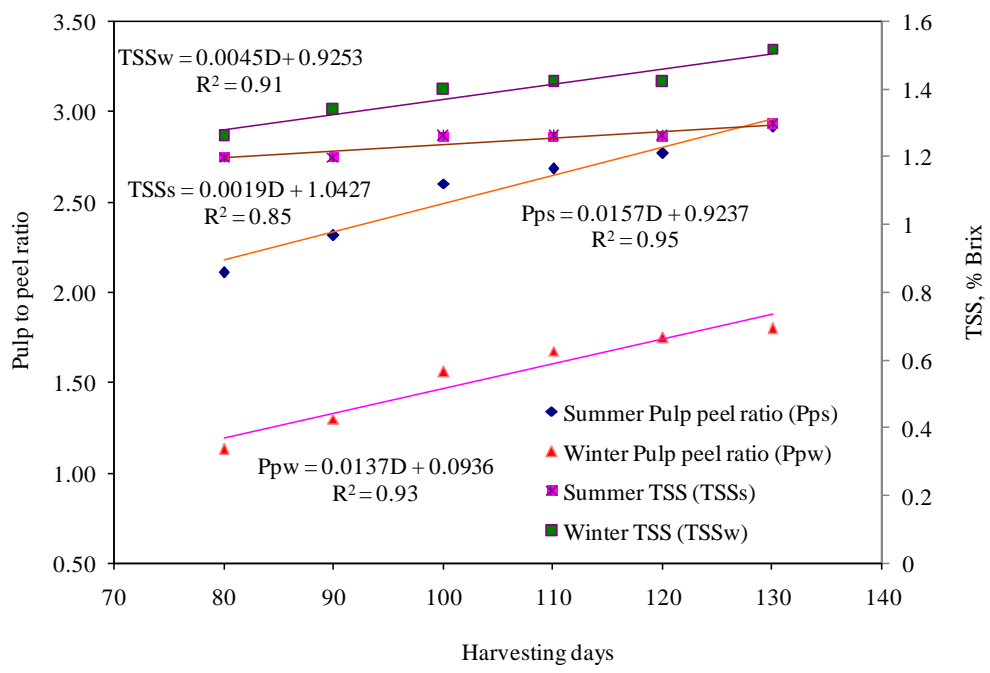

Fig.4. Effect of harvesting days on pulp to peel ratio and TSS of Sabri Kola. 


\section{Pulp to peel ratio}

From Figure 3, it was observed that pulp to peel ratio of fruits of BARI Kola 1 increased rapidly in summer season but it increased slowly in winter season with the increase of harvesting days. The maximum pulp to peel ratio was noted at harvesting days of 150 and the minimum at harvesting days of 100. Maximum ratio indicates the end of maturity having maximum yield and shortest shelf-life.

From Figure 4, it was observed that pulp to peel ratio of Sabri Kola increased sharply in summer and winter seasons with the increase in harvesting days. The highest and the lowest values of pulp to peel ratios were found at matured and immature stages, respectively as the pulp thickness developed rapidly and the peel thickness reduced sharply with the physiological advancement of fruits. A linear relationship was found between harvesting days and pulp peel ratio. In summer, the highest and the lowest pulp to peel ratios were found 2.92 and 2.11 whereas in winter these were 1.84 and 1.13, respectively. Pulp to peel ratio was also influenced significantly by seasons (Table 3). The highest pulp to peel ratio was observed in summer compared to that in winter. It might be due to temperature effect on fruit growth. It was also observed for both varieties that there was significant variation among the harvesting days (Table 4). The increasing trend of pulp to peel ratios with the increase of harvesting days was reported by Dadzie (1993, 1994a, b) and Robinson (1996).

Table 3. Effect of season on pulp to peel ratio and TSS of BARI Kola 1 and Sabri Kola.

\begin{tabular}{l|ccccc}
\hline \multirow{2}{*}{ Season } & \multicolumn{2}{|c|}{ BARI Kola 1 } & \multicolumn{2}{c}{ Sabri Kola } \\
\cline { 2 - 5 } & Pulp to peel ratio & TSS (\% Brix) & Pulp to peel ratio & TSS (\%Brix) \\
\hline Summer & $1.62 \mathrm{a}$ & $1.16 \mathrm{~b}$ & $2.57 \mathrm{a}$ & $1.25 \mathrm{~b}$ \\
Winter & $1.49 \mathrm{~b}$ & $1.26 \mathrm{a}$ & $1.54 \mathrm{~b}$ & $1.40 \mathrm{a}$ \\
\hline
\end{tabular}

Table 4. Effect of harvesting days on pulp to peel ratio and TSS of BARI Kola 1 and Sabri Kola.

\begin{tabular}{c|c|c|c|c|c}
\hline \multicolumn{3}{c|}{ BARI Kola 1 } & \multicolumn{3}{c}{ Sabri Kola } \\
\hline $\begin{array}{c}\text { Harvesting } \\
\text { days }\end{array}$ & $\begin{array}{c}\text { Pulp to peel } \\
\text { ratio }\end{array}$ & TSS (\%Brix) & $\begin{array}{c}\text { Harvesting } \\
\text { days }\end{array}$ & $\begin{array}{c}\text { Pulp to peel } \\
\text { ratio }\end{array}$ & TSS (\%Brix) \\
\hline 100 & $1.28 \mathrm{~d}$ & $1.05 \mathrm{c}$ & 80 & $1.62 \mathrm{e}$ & $1.23 \mathrm{~b}$ \\
110 & $1.35 \mathrm{~d}$ & $1.16 \mathrm{~b}$ & 90 & $1.81 \mathrm{~d}$ & $1.27 \mathrm{~b}$ \\
120 & $1.53 \mathrm{c}$ & $1.24 \mathrm{a}$ & 100 & $2.08 \mathrm{c}$ & $1.33 \mathrm{ab}$ \\
130 & $1.63 \mathrm{~b}$ & $1.26 \mathrm{a}$ & 110 & $2.18 \mathrm{bc}$ & $1.34 \mathrm{ab}$ \\
140 & $1.75 \mathrm{~b}$ & $1.27 \mathrm{a}$ & 120 & $2.26 \mathrm{ab}$ & $1.34 \mathrm{ab}$ \\
150 & $1.84 \mathrm{a}$ & $1.27 \mathrm{a}$ & 130 & $2.36 \mathrm{a}$ & $1.41 \mathrm{a}$ \\
\hline $\mathrm{CV}(\%)$ & 5.62 & 6.04 & $\mathrm{CV}(\%)$ & 7.56 & 6.95 \\
\hline
\end{tabular}




\section{Dry matter content}

Changes of dry matter content of fruits of BARI Kola 1 at different maturity stages in summer and winter seasons are shown in Figure 5. It was observed that DMC increased initially with the progress of maturity up to 120 and 130 DAEF, respectively and after that time, it declined. Furthermore, it revealed that DMC gradually increased while the moisture content decreased with the development of physiological maturity of the fruits. Later, the DMC decreased as the moisture content increased for starting the ripening process. This finding corroborate with Hassan (2010) who reported decreasing trend of DMC (from 32.89 to 27.11\%) of banana with the increase of ripening period (from 2 to 8 days).

It was also observed that the DMC of fruits of Sabri Kola for summer and winter increased gradually up to 100 and 110 DAEF, respectively and later, they were reduced gradually (Fig. 6). The maximum DMC was found in 100 and 110 DAEF while the lowest values obtained in treatment 80 DAEF for both the seasons. The results further indicated that the fruit ripening started from the optimum stage.

Harvesting days of BARI Kola 1 and Sabri Kola caused significant differences in dry matter content for both the seasons (Table 5 and 6). Depending on seasons, dry matter contents of BARI Kola and Sabri Kola were found to vary significantly (Table 5). Results indicated that summer season was superior to winter season in respect of dry matter content. Harvesting stages exhibited insignificant effect on dry matter content in BARI Kola 1 but significant effect on Sabri Kola (Table 6).

\section{Shelf-life}

Data on shelf-life of fruits for summer and winter seasons of BARI Kola 1 and Sabri Kola are presented in Figure 5 and 6. From these Figures, the shelf-life was found to decrease sharply with the increase in harvesting days. For BARI Kola 1, the shelf-life ranged between 6.83 and 11.17 days having the longest shelf-life of 11.17 days in 100 DAEF and the shortest shelf-life of 6.83 days in 150 DAEF in summer. In winter, the highest and the lowest values were 22.33 and 12.5 days in 100 and 150 DAEF, respectively. The variation of shelf-life of the fruits in both the seasons was due to climatic effect.

It was also observed that shelf-life of Sabri Kola ranged between 7.35 and 11.65 days with the longest shelf-life, 11.65 days in 80 DAEF and the shortest, 7.35 days in 130 DAES for summer while for winter the highest and lowest values were 24.6 and 12.35 days in the same DAES, respectively. 


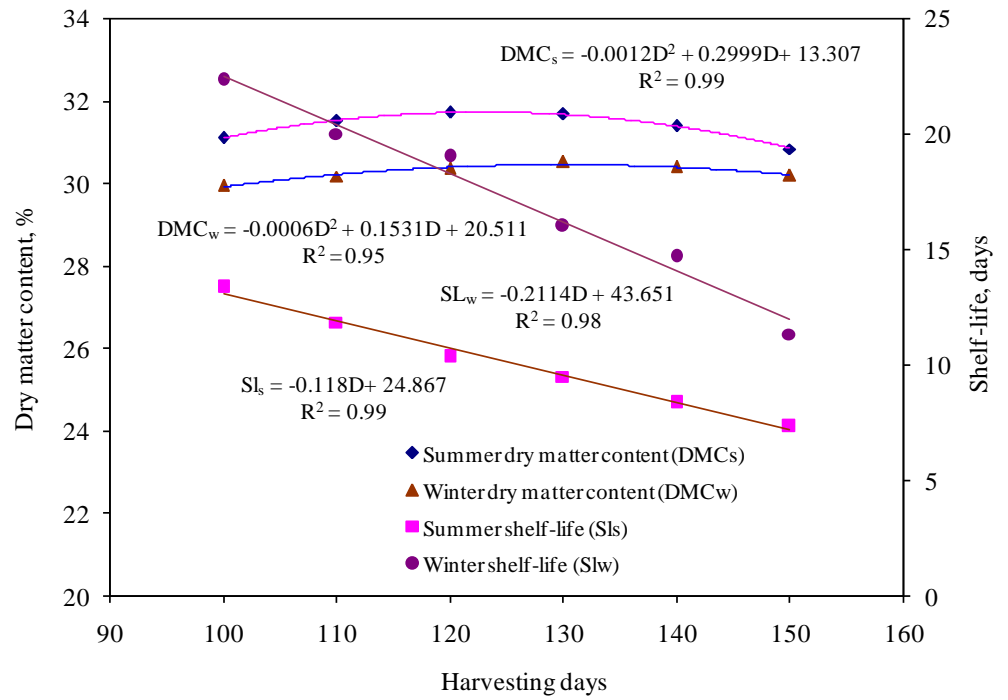

Fig.5. Effect of harvesting days on dry matter content and shelf-life of BARI Kola 1.

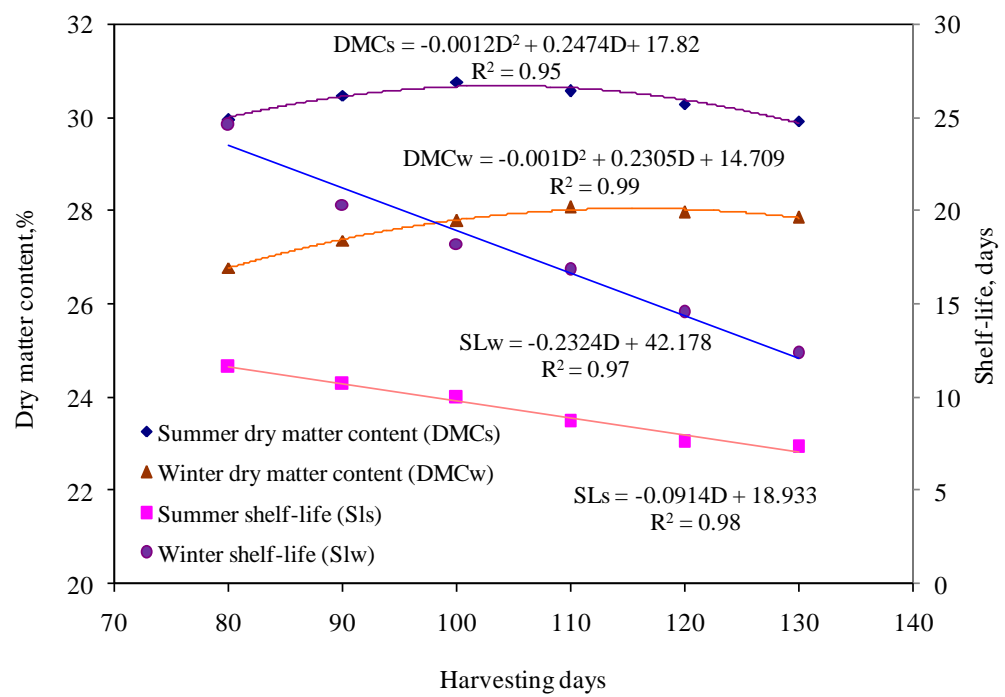

Fig.6. Effect of harvesting days on dry matter content and shelf-life of Sabri Kola.

In regards to seasons, shelf-life of BARI Kola and Sabri Kola varied significantly (Table 5). Results indicate that the longest shelf-life (17.25 days) was found in winter where as the shortest shelf-life ( 9.47 days) was observed in summer. Irrespective of seasons, harvesting stages exhibited significant effect on shelf-life for both the varieties (Table 6). Therefore, shelf-life of Sabri Kola was higher 
than that of BARI Kola 1 in respect of harvesting days. Narayan and Mustaffa (2007) reported the similar results in shelf-life of banana.

Table 5. Effect of season on yield, dry matter content and shelf-life of BARI Kola 1 and Sabri Kola.

\begin{tabular}{l|c|c|c|c|c|c}
\hline \multirow{3}{*}{ Season } & \multicolumn{3}{|c|}{ BARI Kola 1 } & \multicolumn{3}{c}{ Sabri Kola } \\
\cline { 2 - 7 } & $\begin{array}{c}\text { Yield } \\
\mathrm{t} \mathrm{ha}^{-1}\end{array}$ & $\begin{array}{c}\text { Dry matter } \\
\text { content } \\
\%(\mathrm{db})\end{array}$ & $\begin{array}{c}\text { Shelf-life } \\
\text { days }\end{array}$ & $\begin{array}{c}\text { Yield } \\
\mathrm{t} \mathrm{ha}^{-1}\end{array}$ & $\begin{array}{c}\text { Dry matter } \\
\text { content } \\
\%(\mathrm{db})\end{array}$ & $\begin{array}{c}\text { Shelf-life } \\
\text { days }\end{array}$ \\
\hline Summer & $32.44 \mathrm{a}$ & $31.30 \mathrm{a}$ & $9.47 \mathrm{~b}$ & $24.74 \mathrm{a}$ & $43.53 \mathrm{a}$ & $9.33 \mathrm{~b}$ \\
Winter & $23.68 \mathrm{~b}$ & $30.60 \mathrm{~b}$ & $17.25 \mathrm{a}$ & $17.79 \mathrm{~b}$ & $38.22 \mathrm{~b}$ & $17.82 \mathrm{a}$ \\
\hline
\end{tabular}

\section{Determination of optimum maturity days of BARI Kola 1 and Sabri Kola}

Scaling values of all the following physico-chemical parameters such as TSS, DMC, Firmness, angularity, shelf-life, yield, Pp for particular harvesting stage were summarized.

BARI Kola 1: Optimum maturity of banana was determined on the basis of physico-chemical parameters. Relation between sum of score of physicochemical parameters and harvesting stages of BARI Kola 1 are shown in Figure 7. From this figure, it was found that scoring value gradually increased up to 120 harvesting days in summer and up to 130 harvesting days in winter and they gradually decreased with the increase of harvesting days. Optimum values were found near 120 harvesting days in summer and 130 harvesting days in winter, respectively.

Table 6. Effect of harvesting days on yield, dry matter content and shelf-life of BARI Kola 1and Sabri Kola.

\begin{tabular}{c|c|c|c|c|c|c|c}
\hline \multicolumn{5}{c|}{ BARI Kola 1 } & \multicolumn{4}{c}{ Sabri Kola } \\
\hline $\begin{array}{c}\text { Harvesting } \\
\text { days }\end{array}$ & $\begin{array}{c}\text { Yield } \\
\mathrm{t} \mathrm{ha}^{-1}\end{array}$ & $\begin{array}{c}\text { Dry } \\
\text { matter } \\
\text { content } \\
\%(\mathrm{db})\end{array}$ & $\begin{array}{c}\text { Shelf- } \\
\text { life } \\
\text { days }\end{array}$ & $\begin{array}{c}\text { Harvesting } \\
\text { days }\end{array}$ & $\begin{array}{c}\text { Yield } \\
\mathrm{t} \mathrm{ha}^{-1}\end{array}$ & $\begin{array}{c}\text { Dry } \\
\text { matter } \\
\text { content } \% \\
(\mathrm{db})\end{array}$ & $\begin{array}{c}\text { Shelf-life } \\
\text { days }\end{array}$ \\
\hline 100 & $21.75 \mathrm{~d}$ & 30.53 & $16.75 \mathrm{a}$ & 80 & $14.23 \mathrm{e}$ & $39.61 \mathrm{~d}$ & $18.13 \mathrm{a}$ \\
110 & $25.20 \mathrm{c}$ & 30.85 & $15.33 \mathrm{~b}$ & 90 & $17.88 \mathrm{~d}$ & $40.71 \mathrm{bc}$ & $15.52 \mathrm{~b}$ \\
120 & $28.46 \mathrm{~b}$ & 31.04 & $14.17 \mathrm{c}$ & 100 & $21.96 \mathrm{c}$ & $41.40 \mathrm{ab}$ & $14.13 \mathrm{c}$ \\
130 & $29.71 \mathrm{ab}$ & 30.98 & $12.50 \mathrm{~d}$ & 110 & $23.73 \mathrm{~b}$ & $41.48 \mathrm{a}$ & $12.75 \mathrm{~d}$ \\
140 & $31.04 \mathrm{ab}$ & 31.28 & $11.75 \mathrm{~d}$ & 120 & $24.45 \mathrm{~b}$ & $41.10 \mathrm{abc}$ & $11.07 \mathrm{e}$ \\
150 & $32.17 \mathrm{a}$ & 31.01 & $9.67 \mathrm{e}$ & 130 & $25.33 \mathrm{a}$ & $40.65 \mathrm{c}$ & $9.85 \mathrm{f}$ \\
\hline $\mathrm{CV}(\%)$ & 8.55 & 2.26 & 3.79 & $\mathrm{CV}(\%)$ & 3.85 & 1.32 & 3.47 \\
\hline
\end{tabular}


The variation in optimum maturity stage might be due to temperature and humidity at different seasons. BARI Kola 1 was harvested within 120-140 days after emergence of flowers. During this period, minimum postharvest losses occurred and got optimum storage life i.e shelf-life. When fruits were harvested before optimum maturity, postharvest losses and storage life increased but quality decreased while harvested after optimum maturity, postharvest losses of fruits increased but storage life and quality decreased. Best fitted two degree polynominal regression equations were attained for optimum harvesting maturity stage.

Sabri Kola: The scoring values of Sabri Kola for both the seasons were changed over the harvesting days (Figure 8). The values increased gradually up to 100 and 110 days of harvesting and later it declined. The maximum value of scoring was obtained at 100 and 110 DAEF in summer and winter, respectively and those were the optimum harvesting stages of the Sabri Kola. Best fitted three degree polynominal regression equations were attained for optimum harvesting maturity stage of Sabri Kola.

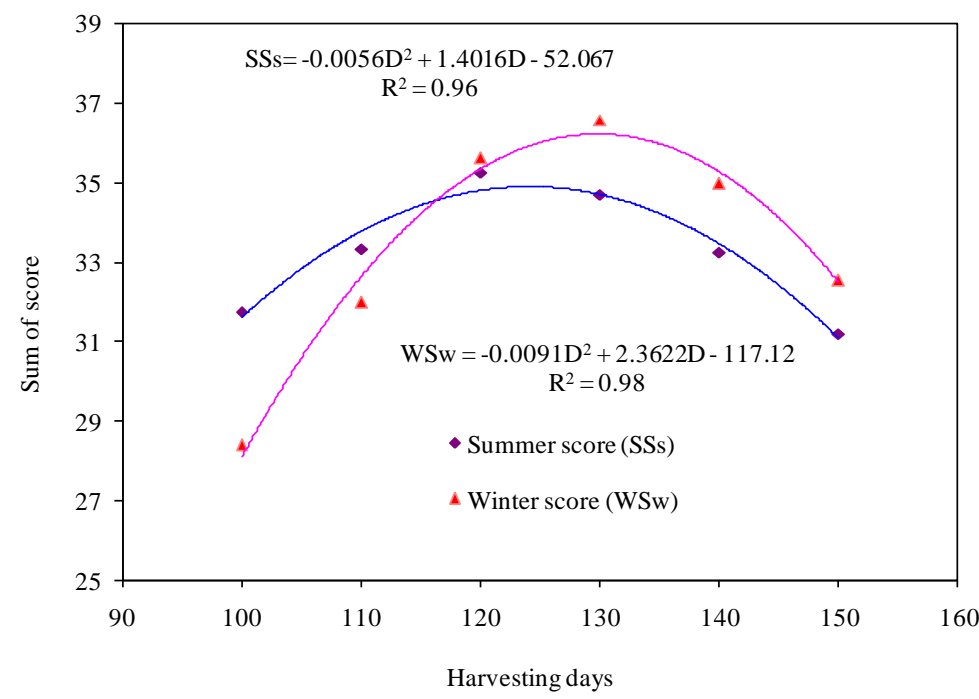

Fig.7. Effect of harvesting days on physico-chemical parameters of BARI Kola 1. 


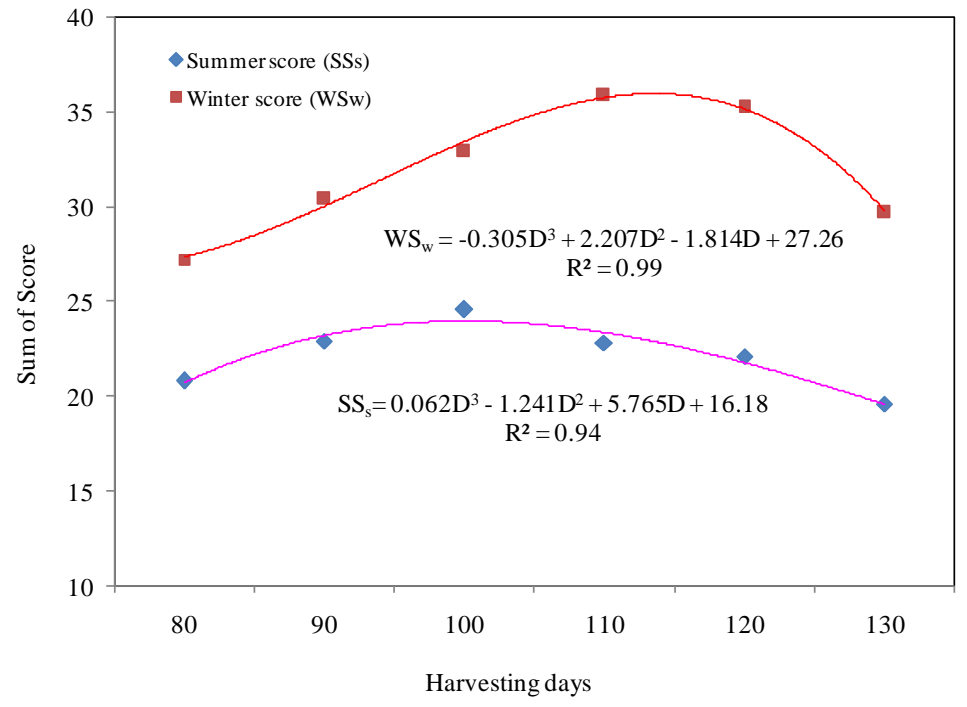

Fig. 8. Effect of harvesting days on physico-chemical parameters of Sabri Kola.

\section{Degree days}

Degree days of BARI Kola 1 and Sabri Kola are shown in Fig. 9.The degree days of BARI Kola 1 and Sabri Kola were found to be 1750 and 1620, respectively. Similar results of Williams banana bunch from emergence to harvest maturity ranged from 950 to 1050 was obtained in South Africa by Robinson et al. (1992).

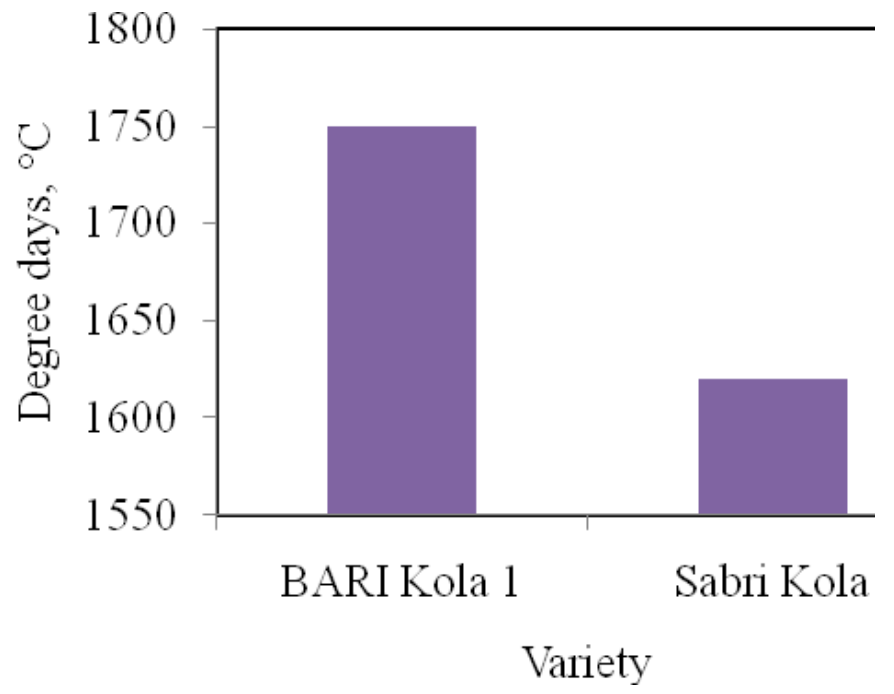

Fig.9. Degree days of BARI Kola 1 and Sabri Kola. 


\section{Conclusion}

The study clearly showed that optimum harvesting days of BARI Kola 1 and Sabri Kola were found to be 120 and 130 days DAEF in summer, and 100 and 110 days DAEF in winter, respectively. Shelf-lives of BARI Kola 1 and Sabri Kola at optimum maturity stages obtained 10.33 and 15.50 days in summer and 10.00 and 16.80 days in winter, respectively. At optimum maturity, angularity of BARI Kola 1 and Sabri Kola was found at $145.20^{\circ}$ and $145.73^{\circ}$ and $145.48^{\circ}$ and $142.99^{\circ}$ in summer and winter seasons, respectively. BARI Kola 1 and Sabri Kola had 1750 and 1620 degree days, respectively. Farmers and traders should harvest banana at or before optimum harvesting days to store for long period and to attain good quality fruits.

\section{References}

Ara, N., M. K. Bashar, W. Kabir and M. O. Kaisar. 2009. Variety and planting time effect on growth and yield of banana (Musa sapientum L.). Journal of Agricultural Research, 47(2):153-163.

Dadzie, B. K. 1993. Quarterly report for the INIBAP/FHIA/NRI (ODA Holdback) project on postharvest cooking banana and plantation characterization (OctoberDecember 1993).

Dadzie, B. K. 1994a. Quarterly report for the INIBAP/FHIA/NRI (ODA Holdback) project of postharvest cooking banana and plantation characterization (OctoberDecember 1994).

Dadzie, B. K. 1994b. Six monthly report for the INIBAP/FHIA/NRI (ODA Holdback) project of postharvest cooking banana and plantation characterization (AprilSeptember 1994).

Dadzie, B. K. and J. E. Orchard.1997. Routine Postharvest Screening of Banana /Plantain Hybrids: Criteria and Method, Inihap Technical Guidelines.

Haque, M. A. 1988. Kalar Bagan (in bengali). 3rd ed. Banana Research Project. Bangladesh Agricultural University, Mymensingh, P.24.

Harman, J. E. 1981. Kiwifruit maturity. The Orchardist of New Zealand (May), 126-128.

Hassan, M. K., B. L. D. Chowdhury and N. Akhter. 2010. Postharvest loss assessment: A study to formulate policy for loss reduction of fruits and vegetables and socioeconomic uplift of the stakeholders, Final Report (PR \# 8/08). National Food Policy Capacity Strengthening Programme.

Jindal, P. C. 1985. Grapes. In: Fruits of India Tropical and Sub-tropical (edited by T. K. Bose). Naya Prokash, Calcutta six, India.

Kader, A. A. 1994. Fruit maturity, ripening and quality relationships. Perishables Handling, Newsletter, 80:2.

Knowledge Master. 2003. University of Hawaii, College of Tropical Agriculture and Human Resources, University of Hawaii-Manoa. Computer Resource Database. http://www.extento.hawaii.edu/kbase/crop/crops/banana.htm. 
Kushman, L. J., D. T. Pope and J. A. Warren.1966. A rapid method of estimating dry matter content of sweet patato. P. 240 in Proc. South Agr. Workers Meetings $64^{\text {th }}$ Annual Convention.

Morton, J. 1987. Banana (Musa x paridasiaca). In: Fruits of warm climates. Julia F. Morton, Miami, FL., Pp. 29-46.

Mpyshameem. 2010. Banana. Horticulture, www.e-krishi.co.cc/horticulture/banana, accessed on $03 / 26 / 2012$.

Narayan, C. K. and M. M. Mustaffa. 2007. Influence of maturity on shelf-life and quality changes in banana during storage under conditions. Indian Journal of Horticulture, 64(1):12-18.

Robinson, J. C. 1996. Bananas and Plantains. CAB International, UK, Pp.238.

Robinson, J. C., T. Anderson and K. Eckstein.1992. The influence of functional leaf removal of flower emergence on components of yield and photosynthetic compensation in banana. Journal of Horticultural Science, 67:403-410. 